\title{
Uji Toksisitas dan Surfaktan Linear Alkilbenzene Sulfonate (LAS) pada Insang dan Hati Benih Ikan Kerapu Bebek
}

\author{
Toxicity and Linear Alkilbenzene Sulfonate (LAS) Surfactant Gills and Liver of Humpback \\ Grouper Seed \\ Devi Kristianti ${ }^{1 *}$, Resty Paramitha ${ }^{2}$, Fitri Agustriani ${ }^{1}$, Gusti Diansyah ${ }^{1}$ \\ ${ }^{1}$ Program Studi Pengolahaan Lingkungan, Program Pascasarjana Universitas Sriwijaya, \\ Palembang 30139 \\ ${ }^{2}$ Program Studi Ilmu Kelautan, Fakultas Matematika dan Ilmu Pengetahuan Alam, \\ Universitas Sriwijaya, Indralaya 30662 \\ ${ }^{*}$ Penulis untuk korespondensi: devi_bizzare@yahoo.com
}

\begin{abstract}
LAS is surfactant that is most commonly used because this surfactant is the main cleaning substance contained in detergent. Waste of detergent can give side effects in the tissue of organisms, especially on the gills and liver of fish. The aims of this research were to analyze the toxic effects arised from LAS surfactant to the survival of fish seed experiment with different concentrations, to determine levels of LAS surfactant tolerated and to analyze the gills and liver damage arising from LAS surfactant to fish seed experiment. The test of LAS surfactant toxicity on fish seed experiment was conducted using the laboratory of experimental method, while the testing of gills and liver histology of fish seed experiment with paraffin method and Hematoxylin Eosin (HE) staining. The results showed that LAS surfactant gave toxic effects on Humpback Grouper Seed (Cromileptes altivelis) and gave effect such damage to the gills and liver histology. Toxicity and tissue damage rose as the increase of LAS surfactant concentration. LAS surfactant levels were able to be tolerated by Humpback Grouper Seed test not more than $0,253 \mathrm{mg} / \mathrm{l}$.
\end{abstract}

Keywords: toxicity, LAS surfactant, cromileptes altivelis, gills and liver histology

\begin{abstract}
ABSTRAK
Surfaktan LAS merupakan surfaktan yang paling umum digunakan karena surfaktan ini merupakan bahan pembersih utama yang terdapat didalam detergen. Limbah detergen dapat memberikan efek samping pada jaringan organisme khususnya ikan yaitu pada insang dan hati. Tujuan penelitian ini adalah menganalisis efek toksik yang ditimbulkan dari surfaktan LAS terhadap kelangsungan hidup benih ikan dan menentukan kadar surfaktan LAS yang mampu ditoleransi dan menganalisis kerusakan insang dan hati yang ditimbulkan dari surfaktan LAS terhadap benih ikan. Uji toksisitas surfaktan LAS terhadap benih ikan uji dilakukan dengan metode eksperimental laboratorium, sedangkan pengujian histologi insang dan hati benih ikan uji dengan metode parafin dan pewarnaan Hematoksilin Eosin (HE). Hasil penelitian menunjukkan bahwa Surfaktan LAS memberikan efek toksik terhadap benih ikan kerapu bebek (Cromileptes altivelis) serta memberikan pengaruh berupa kerusakan pada histologi insang dan hati. Toksisitas dan kerusakan jaringan meningkat seiring dengan bertambahnya konsentrasi surfaktan LAS. Kadar surfaktan LAS yang mampu ditoleransi oleh benih ikan uji yaitu tidak lebih dari
\end{abstract}


$0,253 \mathrm{mg} / \mathrm{l}$

Kata kunci: toksisitas, surfaktan LAS, Cromileptes altivelis, histologi insang dan hati

\section{PENDAHULUAN}

Limbah detergen termasuk polutan yang dapat mencemari lingkungan karena didalamnya terdapat zat yang disebut Linear Alkilbenzene Sulfonate (LAS) yang merupakan limbah rumah tangga. Dalam ekotoksikologi, sejumlah besar tes mendapatkan bahwa LAS dapat menyebabkan toksisitas akut dan kronik pada organisme akuatik (Ismarti et al., 2017). Adanya masukan air limbah detergen yang berasal dari kegiatan rumah tangga ke perairan akan mempengaruhi kehidupan organisme yang terdapat di dalamnya khusunya ikan, dari pengaruh secara fisiologis hingga yang dapat mematikan. Salah satu ikan yang dapat terkontaminasi kandungan LAS pada detergen yaitu ikan kerapu bebek (Cromileptes altivelis) karena ikan ini dapat dijumpai di perairan dekat pantai, daerah terumbu karang, dan muara sungai sehingga diperkirakan akan lebih mudah terkontaminasi oleh limbah detergen.

Penelitian mengenai uji toksisitas dan uji histologi insang dan hati surfaktan Linear Alkilbenzene Sulfonate (LAS) terhadap ikan kerapu bebek belum ada karena dari beberapa penelitian sebelumnya hanya beberapa yang menggunakan ikan air laut dan hampir seluruhnya menggunakan ikan air tawar. Oleh karena itu, penelitian ini bertujuan untuk menguji toksisitas dan uji histologi insang dan hati surfaktan LAS pada skala laboratorium untuk menganalisis efek toksik yang ditimbulkan dari surfaktan LAS terhadap kelangsungan hidup benih ikan kerapu bebek dengan konsentrasi yang berbeda, menentukan kadar surfaktan LAS yang mampu ditoleransi oleh benih ikan kerapu bebek dan menganalisis kerusakan insang dan hati yang ditimbulkan dari surfaktan Linear Alkilbenzene Sulfonate (LAS) terhadap benih ikan kerapu bebek.

\section{BAHAN DAN METODE}

Penelitian mengenai uji toksisitas surfaktan LAS serta uji histologi insang dan hati benih ikan kerapu bebek dilaksanakan pada tanggal 22 Desember 2015 - 11 Januari 2016 di Balai Besar Perikanan Budidaya Laut (BBPBL) Lampung yang berlokasi di Desa Hanura Kecamatan Padang Cermin Kabupaten Pesawaran Lampung Selatan Provinsi Lampung. Selanjutnya pengamatan mikroskop dan analisis preparat insang dan hati benih ikan kerapu bebek dilaksanakan pada tanggal 24-25 Februari 2016 di Balai Karantina Ikan dan Pengendalian Mutu dan Keamanan Hasil Perikanan Kelas II Palembang yang berlokasi di Jalan Akses Bandara Internasional Sultan Mahmud Badarudin II Kota Palembang Provinsi Sumatera Selatan.

Bahan uji yang digunakan pada penelitian ini yaitu surfaktan LAS dan hewan uji yang digunakan yaitu benih ikan kerapu bebek yang berumur 55 - 75 hari dengan panjang $4-5 \mathrm{~cm}$ serta berat $1-$ 2,5 gram dan berasal dari Balai Besar Pengembangan Budidaya Laut (BBPBL) Lampung. Benih ikan yang digunakan yaitu sebanyak 240 ekor dan pada masingmasing perlakuan atau konsentrasi dimasukkan 10 ekor ikan. Penelitian ini dilakukan dengan dua tahapan:

\section{Tahap Pengujian Toksisitas Surfaktan LAS terhadap Benih Ikan Kerapu Bebek}

\section{Tahap Persiapan}

Sebelum uji dilakukan, benih ikan kerapu bebek (Cromileptes altivelis) diaklimatisasi terlebih dahulu selama 1 hari. Selama aklimatisasi tersebut, benih ikan kerapu bebek diberi artemia dan diberi aerasi. Wadah uji yang digunakan yaitu toples 18 buah ukuran 10 liter. Persiapan meliputi pembersihan toples, pengaturan letak toples, penyiapan 
aerator, selang, batu aerasi dan memasukkan air laut sebanyak 5 liter ke masing-masing toples yang akan digunakan. Pembuatan larutan uji mengacu pada SNI 06-6989.51-2005 yaitu dengan cara melarutkan bahan uji yaitu Serbuk LAS $\left(\mathrm{C}_{12} \mathrm{H}_{25} \mathrm{OSO}_{3} \mathrm{Na}\right)$ sebanyak 1 gram dengan $5000 \mathrm{ml}$ air laut ke dalam labu ukur $5000 \mathrm{ml}$ dan dihomogenkan. Larutan ini memiliki konsentrasi LAS $\left(\mathrm{C}_{12} \mathrm{H}_{25} \mathrm{OSO}_{3} \mathrm{Na}\right)$ sebesar $1000 \mathrm{mg} / \mathrm{l}$ atau $1000 \mathrm{ppm}$.

\section{Uji Pendahuluan}

(Goang, 2018), mengatakan uji pendahuluan bertujuan untuk mengetahui nilai konsentrasi ambang atas $\left(\mathrm{LC}_{100}-24\right.$ jam) dan konsentrasi ambang bawah ( $\mathrm{LC}_{0^{-}}$ 48 jam) yang kemudian datanya digunakan sebagai acuan untuk menentukan konsentrasi pada uji utama. Konsentrasi bahan uji yang digunakan dalam penelitian pendahuluan berdasarkan basis 10 deret logaritmik menurut (Selatan et al., 2019) yaitu $0,01 \mathrm{mg} / \mathrm{l} ; 0,1 \mathrm{mg} / \mathrm{l} ; 1$ $\mathrm{mg} / \mathrm{l} ; 10 \mathrm{mg} / \mathrm{l} ; 100 \mathrm{mg} / \mathrm{l}$ dan satu kontrol tanpa penambahan larutan uji. Jumlah ikan uji yang digunakan dalam uji pendahuluan ini adalah sebanyak 10 ekor untuk setiap toples. Toples yang digunakan sebanyak 6 buah, diisi air sebanyak 5 liter dan dipasang aerator. Pengamatan mortalitas dilakukan dalam selang waktu berdasar deret geometris yaitu 15 menit, 30 menit, 1 jam, 2 jam, 4 jam, 8 jam, 16 jam, 24 jam, 36 jam dan 48 jam.

\section{Uji Utama}

Setelah dilakukan uji pendahuluan, selanjutnya dilakukan uji utama untuk mengetahui konsentrasi dimana ikan uji mati 50\% selama jangka waktu 96 jam ( $\mathrm{LC}_{50^{-}} 96$ jam). Perlakuan dalam uji ini dilakukan dengan diferensiasi 5 konsentrasi detergen yang berbeda dan dilakukan dengan 3 kali pengulangan. Jumlah ikan uji yang digunakan dalam uji utama yaitu sebanyak 10 ekor untuk masing - masing toples. Toples yang digunakan sebanyak 18 buah, diisi air sebanyak 5 liter kemudian dipasang aerator. Menurut (Kurniawan, Mardiadi and Febriyeni, 2015).

\section{Kualitas Air}

Kualitas air yang diamati meliputi pengukuran oksigen terlarut, $\mathrm{pH}$, suhu, dan salinitas yang dilakukan pada awal dan akhir penelitian. Pengukuran kualitas air ini dilakukan untuk mengetahui tingkat kelayakan media uji terhadap benih ikan Kerapu Bebek saat penelitian.

\section{Kelangsungan Hidup (Survival Rate)}

Kelangsungan hidup atau survival rate (SR) merupakan persentasi jumlah benih ikan kerapu bebek yang masih hidup setelah pemberian bahan uji yaitu LAS. Perhitungan ini dilakukan pada akhir penelitian dan perhitungannya menggunakan rumus menurut (Mubin, 2017) adalah sebagai berikut:

$$
S R=\frac{\mathrm{N}_{\mathrm{t}}}{\mathrm{N}_{\mathrm{o}}} \times 100 \%
$$

Keterangan :

$\mathrm{SR}=$ Tingkat Kelangsungan hidup hewan Uji (\%)

$\mathrm{N}_{\mathrm{t}}=$ Jumlah ikan uji yang hidup pada akhir penelitian (ekor)

$\mathrm{N}_{0}=$ Jumlah ikan uji yang hidup pada awal penelitian (ekor)

\section{Analisis Data}

Data mortalitas benih ikan kerapu bebek pada uji utama merupakan angka acuan untuk mengetahui hubungan logaritma konsentrasi dan probit mortalitas hewan uji yang merupakan fungsi linear dari $\mathrm{Y}=\mathrm{a}+\mathrm{bX}$. Analisis data $\mathrm{LC}_{50}-96$ jam pada uji toksisitas surfaktan LAS terhadap benih ikan kerapu bebek dianalisis menggunakan EPA Probit Analysis Program yang datanya didapatkan dari data mortalitas hewan pada uji utama.

\section{Tahap pengujian histologi insang dan hati benih ikan Kerapu Bebek}

Pengujian histologi insang dan hati 
benih ikan kerapu bebek dilakukan menggunakan metode parafin dan pewarnaan Hematoksilin dan Eosin (HE). Tahapan pembuatan preparat insang dan hati benih ikan Kerapu Bebek yaitu tahap pengambilan jaringan, tahap fiksasi, tahap dehidrasi, tahap penjernihan (clearing), tahap infiltrasi, tahap pengeblokan (embedding), tahap pemotongan, tahap pewarnaan yang meliputi deparafinasi, proses rehidrasi, proses pewarnaan, proses dehidrasi, mounting dan tahap penutupan (Putri and Purwiyanto, 2014).

Pada uji histologi, data gambaran jaringan insang dan hati yang telah diamati menggunakan mikroskop dianalisis secara deskriptif untuk mengetahui pengaruh surfaktan LAS terhadap kondisi insang dan hati benih ikan kerapu bebek. Hal ini dilakukan dengan cara menganalisis kerusakan jaringan insang dan hati ikan yang terdapat pada kelompok kontrol dan kelompok perlakuan atau konsentrasi.

\section{HASIL DAN PEMBAHASAN}

\section{Kualitas Air}

Data pada Tabel 1 menunjukkan variabel oksigen terlarut berada pada kisaran 2,00 - 5,79 mg/l. Pada saat awal penelitian, kandungan oksigen pada konsentrasi kontrol atau $0 \mathrm{mg} / \mathrm{l}$ maupun konsentrasi yang mengandung surfaktan LAS masih termasuk ke dalam kategori layak yaitu > $5 \mathrm{mg} / \mathrm{l}$ namun kandungan oksigen pada konsentrasi kontrol dan konsentrasi yang mengandung LAS mengalami penurunan seiring dengan lamanya waktu pemaparan yaitu mencapai $2,00 \mathrm{mg} / \mathrm{l}$. Variabel suhu berada pada kisaran 26,8-30,9 ${ }^{\circ} \mathrm{C}$ yang masih termasuk ke dalam kategori layak.

Tabel 1. Hasil pengukuran kualitas air selama penelitian

\begin{tabular}{lll}
\hline \multicolumn{1}{c}{ Parameter } & Hasil Pengamatan & $\begin{array}{l}\text { Tingkat Kelayakan } \\
\text { (Subyakto dan Cahyaningsih, 2003) }\end{array}$ \\
\hline Oksigen terlarut & $2,00-5,79$ & $>5 \mathrm{mg} / \mathrm{l}$ \\
pH & $7,64-8,58$ & $7,8-8,3$ \\
Salinitas & $30-32$ & $28-35 \mathrm{ppt}$ \\
Suhu & $26,8-30,9^{\circ} \mathrm{C}$ & $28-32^{\circ} \mathrm{C}$ \\
\hline
\end{tabular}

Uji Toksisitas Surfaktan LAS terhadap Benih Ikan Kerapu Bebek Uji Pendahuluan

Berdasarkan hasil uji pendahuluan yang dilakukan diperoleh bahwa pada konsentrasi $10 \mathrm{mg} / \mathrm{l}$ semua hewan uji mati selama 24 jam dan pada konsentrasi 1 $\mathrm{mg} / \mathrm{l}$ semua hewan uji hidup selama 48 jam. Dari hasil tersebut, menunjukkan bahwa nilai ambang atas adalah sebesar 10 $\mathrm{mg} / \mathrm{l}$ dan nilai ambang bawah sebesar 1 $\mathrm{mg} / \mathrm{l}$. Tingkat mortalitas berdasarkan Tabel 2 dapat dilihat bahwa pada konsentrasi $100 \mathrm{mg} / \mathrm{l}$ benih ikan kerapu bebek mengalami kematian seluruhnya dalam waktu kurang dari 15 menit dengan menunjukkan gejala pergerakan tidak normal dan melompat-lompat ke atas. Pada konsentrasi $10 \mathrm{mg} / \mathrm{l}$ benih ikan mengalami kematian sebanyak 7 ekor pada 1 jam pertama dan pada jam ke 2 seluruh benih ikan tidak dapat bertahan hidup dengan menunjukkan gejala stres, berada di dasar wadah uji, dan tidak ada respon terhadap sentuhan. Sedangkan pada konsentrasi $0 \mathrm{mg} / \mathrm{l}$ atau kontrol pergerakan benih ikan terlihat normal, berenang aktif dan tidak menunjukkan gejala stres. 
Tabel 2. Data mortalitas uji pendahuluan

\begin{tabular}{|c|c|c|c|c|c|c|c|c|c|c|}
\hline \multirow[b]{2}{*}{$\begin{array}{l}\text { Konsentrasi LAS } \\
(\mathrm{mg} / \mathrm{l})\end{array}$} & \multicolumn{9}{|c|}{ Mortalitas (ekor) } & \multirow[b]{2}{*}{$\begin{array}{l}48 \\
\text { jam }\end{array}$} \\
\hline & $\begin{array}{l}15 \\
\mathrm{mnt}\end{array}$ & $\begin{array}{l}30 \\
\mathrm{mnt}\end{array}$ & $\begin{array}{l}1 \\
\text { jam }\end{array}$ & $\begin{array}{l}2 \\
\text { jam }\end{array}$ & $\begin{array}{c}4 \\
\text { jam }\end{array}$ & $\begin{array}{c}8 \\
\text { jam }\end{array}$ & $\begin{array}{c}16 \\
\text { jam }\end{array}$ & $\begin{array}{l}24 \\
\text { jam }\end{array}$ & $\begin{array}{l}36 \\
\text { jam }\end{array}$ & \\
\hline $\mathrm{mg} / \mathrm{l}$ & - & - & - & - & - & - & - & - & & \\
\hline \multirow[b]{2}{*}{$0,01 \mathrm{mg} / \mathrm{l}$} & - & & & & & & & & & \\
\hline & - & - & - & - & - & - & - & - & - & - \\
\hline $0,1 \mathrm{mg} / \mathrm{l}$ & - & - & - & - & - & - & - & - & - & - \\
\hline \multicolumn{11}{|c|}{$1 \mathrm{mg} / \mathrm{l}-\ldots$} \\
\hline $100 \mathrm{mg} / \mathrm{l}$ & 10 & $\mathrm{x}$ & $\mathrm{x}$ & $\mathrm{x}$ & $\mathrm{x}$ & $\mathrm{x}$ & $\mathrm{x}$ & $\mathrm{x}$ & $\mathrm{x}$ & $\mathrm{x}$ \\
\hline
\end{tabular}

Keterangan :

- : Ikan masih hidup x :Tidak ada ikan yang hidup

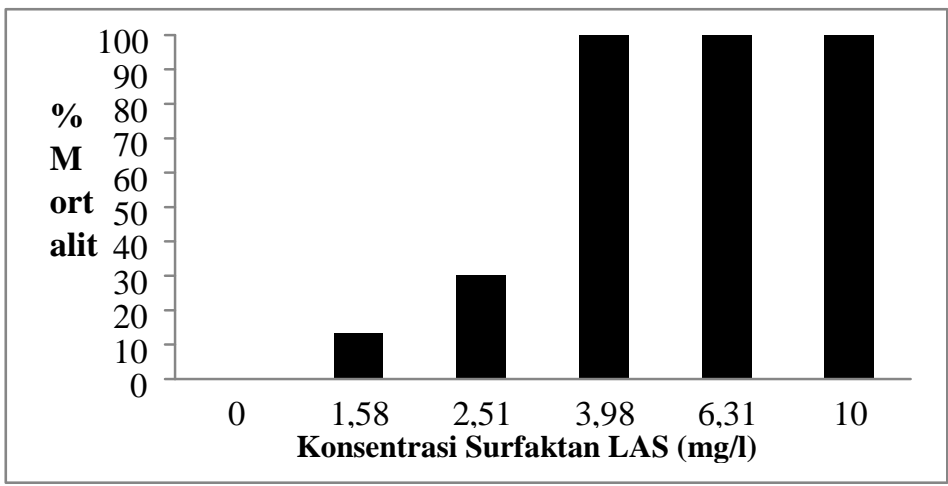

Gambar 1. Histogram rata-rata persentase mortalitas benih ikan kerapu bebek dalam waktu paparan 96 jam

\section{Uji Utama}

Dari Tabel 3 hasil perhitungan yang telah dilakukan didapatkan 6 konsentrasi surfaktan Linear Alkilbenzene Sulfonate yaitu $0 \mathrm{mg} / \mathrm{l}$ (kontrol), $1,58 \mathrm{mg} / \mathrm{l} ; 2,51 \mathrm{mg} / \mathrm{l}$; $3,98 \mathrm{mg} / \mathrm{l} ; 6,31 \mathrm{mg} / \mathrm{l}$; dan $10 \mathrm{mg} / \mathrm{l}$.

Hubungan Logaritma Konsentrasi dan Probit Mortalitas Benih Ikan Kerapu Bebek

Persamaan regresi linear sederhana pada Tabel 4 diartikan bahwa peningkatan konsentrasi surfaktan LAS memberikan pengaruh positif dan memiliki keeratan korelasi terhadap mortalitas benih ikan Kerapu Bebek, dimana pengaruh konsentrasi tersebut sebesar 92,14\% terhadap mortalitas hewan uji.

\section{Uji Utama}

Dari tabel dan gambar tersebut, peningkatan konsentrasi Surfaktan LAS sangat berpengaruh terhadap persentase dimana pada konsentrasi $1,58 \mathrm{mg} / \mathrm{l}$ hewan uji yang mati yaitu $13,3 \%$ dan selanjutnya terjadi peningkatan pada konsentrasi 2,51 $\mathrm{mg} / \mathrm{l}$ menjadi $30 \%$ Sedangkan pada konsentrasi $3,98 \mathrm{mg} / \mathrm{l} ; 6,31 \mathrm{mg} / \mathrm{l}$ dan 10 $\mathrm{mg} / \mathrm{l}$ tingkat persentase mortalitas benih Ikan Kerapu Bebek mencapai tingkat yang paling tinggi yaitu $100 \%$ pada ketiga konsentrasi tersebut dalam waktu 96 jam (Gambar 1). Hal ini sesuai dengan pendapat (Gitarama Mei, dkk, 2016) yang mengatakan bahwa semakin tinggi konsentrasi larutan detergen yang diberikan, maka kemampuan biota uji untuk bertahan hidup akan semakin rendah.

\section{Hubungan Logaritma Konsentrasi dan Probit Mortalitas Benih Ikan Kerapu Bebek}

Persamaan regresi linear sederhana diatas dapat diartikan bahwa peningkatan 
konsentrasi surfaktan LAS memberikan pengaruh positif dan memiliki keeratan korelasi terhadap mortalitas benih ikan Kerapu Bebek, dimana pengaruh konsentrasi tersebut sebesar 92,14\% terhadap mortalitas hewan uji (Gambar 2).

Nilai LC $_{50}-96$ jam surfaktan LAS berdasarkan hasil analisa statistik menggunakan EPA Probit Analysis
Program yaitu sebesar 2,533 mg/l yang artinya pada konsentrasi ini 50\% dari jumlah benih ikan Kerapu Bebek dalam pengujian tidak dapat bertahan hidup dalam waktu paparan 96 jam. Tingkat daya racun atau toksisitas berdasarkan nilai $\mathrm{LC}_{50}-96$ jam suatu bahan pencemar pada ikan dibedakan menjadi beberapa kriteria (Tabel 6).

Tabel 3. Data persentase mortalitas benih ikan kerapu bebek dalam waktu

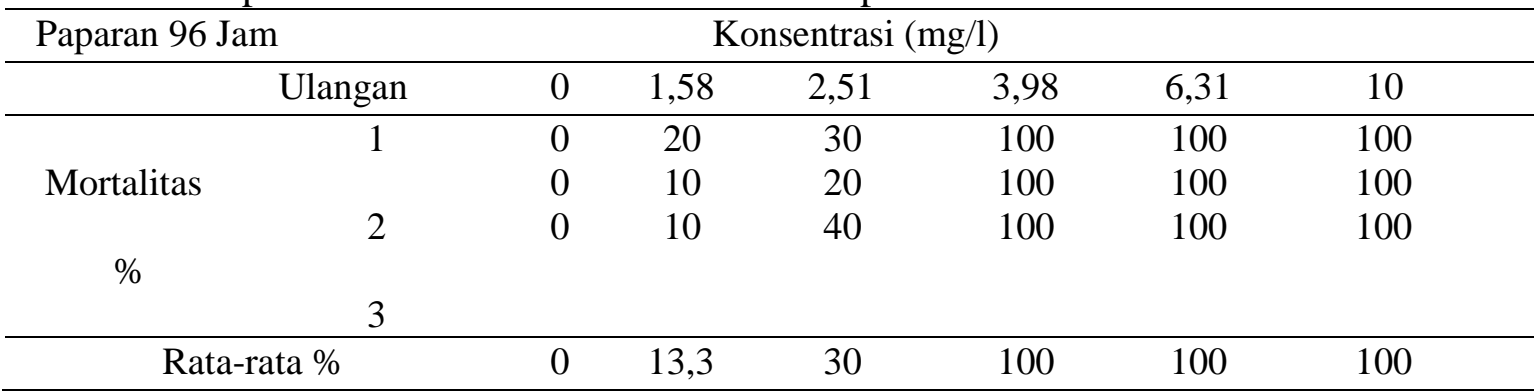

Tabel 4. Statistik regresi logaritma konsentrasi surfaktan las dengan probit mortalitas benih ikan kerapu bebek menggunakan ANOVA

\begin{tabular}{|c|c|}
\hline & \\
\hline$R$ & 0,9214 \\
\hline$R$ Square & 0,8489 \\
\hline Adjusted R Square & 0,8394 \\
\hline Standard Error & 1,2391 \\
\hline Observations & 18 \\
\hline
\end{tabular}

Tabel 5. $\mathrm{LC}_{50}-96$ Jam benih ikan kerapu bebek menggunakan EPA Probit Analysis Program

Estimated LC/EC Values and Confidence Limits

Point

Exposure Conc.

\begin{tabular}{ll}
\hline LC/EC 1.00 & 1.249 \\
LC/EC 5.00 & 1.537 \\
LC/EC 10.00 & 1.716 \\
LC/EC 15.00 & 1.849 \\
LC/EC 50.00 & 2,533 \\
LC/EC 85.00 & 3,471 \\
LC/EC 90.00 & 3,739 \\
LC/EC 95.00 & 4,175
\end{tabular}

Nilai $\mathrm{LC}_{50}-96$ jam Surfaktan Linear Alkilbenzene Sulfonate (LAS) sebesar 2,533 mg/l berada pada klasifikasi 1 - $10 \mathrm{mg} / \mathrm{l}$ yang termasuk ke dalam tingkat daya racun tinggi (Tabel 5).
(Syahrizal and Arifin, 2017) mengatakan bahwa nilai yang aman bagi organisme dari daya racun toksisitas adalah $10 \%$ dari nilai $\mathrm{LC}_{50-96}$ jam. Oleh karena itu, konsentrasi yang diperbolehkan atau 
tergolong aman untuk menjamin kelangsungan hidup benih ikan khususnya pada penelitian ini yaitu ikan Kerapu Bebek di perairan dari surfaktan LAS yaitu tidak lebih dari $0,253 \mathrm{mg} / \mathrm{l}$.

\subsubsection{Kelangsungan Hidup (Survival rate)} Peningkatan konsentrasi Surfaktan LAS dilihat dari Tabel 7 sangat berpengaruh terhadap persentase kelangsungan hidup benih ikan kerapu bebek dimana semakin besar konsentrasi, maka akan semakin menurun persentase kelangsungan hidup hewan uji tersebut (Wiriani, Yarifudin and Jalius, 2018) (Gambar 3).

\section{Histologi Insang dan Hati Benih Ikan Kerapu Bebek}

Data gambaran kerusakan insang dan hati diperoleh dengan dilakukan pengamatan langsung preparat insang benih Ikan Kerapu Bebek (Cromileptes altivelis) menggunakan mikroskop elektron dengan pembesaran 100x dan 400x.

Tabel 6. Kriteria toksisitas untuk pengujian $\mathrm{LC}_{50}$ yang dikeluarkan oleh Komisi Pestisida Departemen Pertanian

\begin{tabular}{ll}
\hline Nilai $\mathrm{LC}_{50}(\mathrm{mg} / \mathrm{l})$ & Tingkat Daya Racun \\
\hline$<1$ & Sangat Tinggi \\
$1-10$ & Tinggi \\
$>10-100$ & Sedang \\
$>100$ & Rendah \\
\hline
\end{tabular}

(Sumber : Komisi Pestisida, 1983)

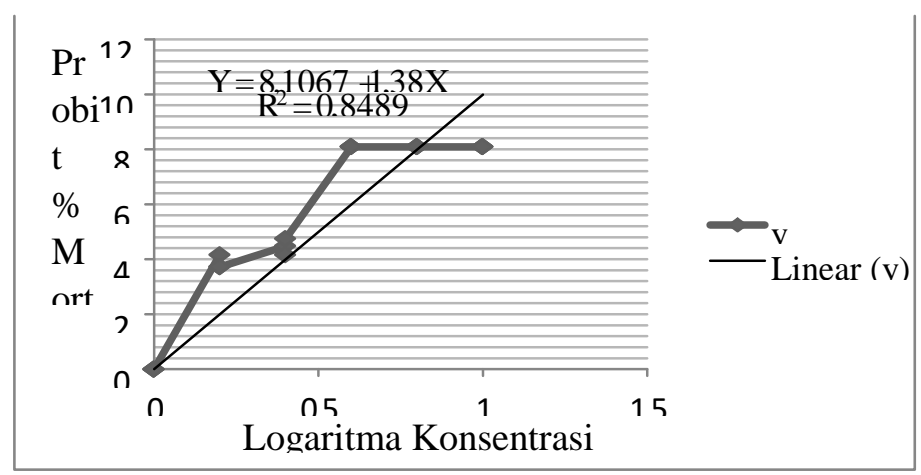

Gambar 2. Hubungan logaritma konsentrasi surfaktan LAS dengan probit mortalitas benih ikan kerapu bebek

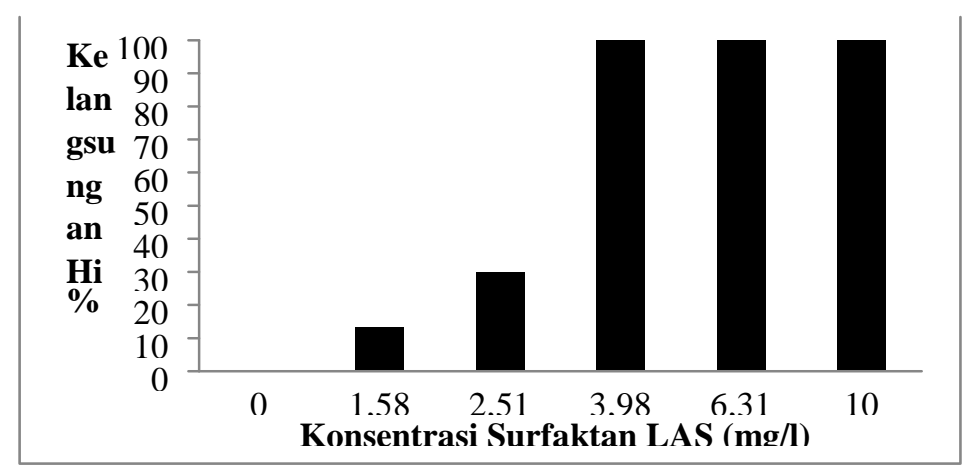

Gambar 3. Histogram rata-rata persentase tingkat kelangsungan hidup benih ikan kerapu bebek dalam waktu paparan 96 jam 
Tabel 7. Data persentase kelangsungan hidup benih ikan kerapu bebek dalam waktu paparan 96 jam

\begin{tabular}{|c|c|c|c|c|c|c|}
\hline \multicolumn{7}{|c|}{ Konsentrasi (mg/l) } \\
\hline & 0 & 1,58 & 2,51 & 3,98 & 6,31 & 10 \\
\hline \multicolumn{7}{|c|}{ Ulangan 100} \\
\hline$\%$ & & 80 & 70 & 0 & 0 & 0 \\
\hline \multirow{2}{*}{$\begin{array}{l}\text { Kelangsungan } 2100 \text { Hidup } \\
\quad 100\end{array}$} & 3 & 90 & 80 & 0 & 0 & 0 \\
\hline & & 90 & 60 & 0 & 0 & 0 \\
\hline \multirow{2}{*}{\multicolumn{2}{|c|}{$\begin{array}{c}100 \\
\text { Rata-rata } \%\end{array}$}} & & & & & \\
\hline & & $\overline{86,7}$ & 70 & 0 & 0 & 0 \\
\hline
\end{tabular}

\section{Histologi Insang Benih Ikan Kerapu Bebek}

Gambar 4 memperlihatkan bagian struktur insang masih lengkap dan lamella sekunder maupun lamella primer terletak pada proporsi yang baik. Kerusakan insang dengan konsentrasi $1,58 \mathrm{mg} / \mathrm{l}$ (Gambar 5) berupa Vakuolalisasi (A), Fusi Epitellamella Sekunder (B), Haemoragie (C) dan Proliferasi Epitellamella Sekunder (D). Pitellamela sekunder Vakuolalisasi terjadi karena ikan kekurangan oksigen sehingga akan menyebabkan benih ikan susah bernafas yang ditandai dengan terbentuknya vakuola atau organel sitoplasma pada lamella sekunder, terlihat tumbuh secara berlebihan atau terjadinya Proliferasi Epitellamella Sekunder. Kerapu Bebek Konsentrasi 2,51 mg/l. Kerusakan insang pada konsentrasi 2,51 $\mathrm{mg} / \mathrm{l}$ mengalami peningkatan kerusakan. Hal ini

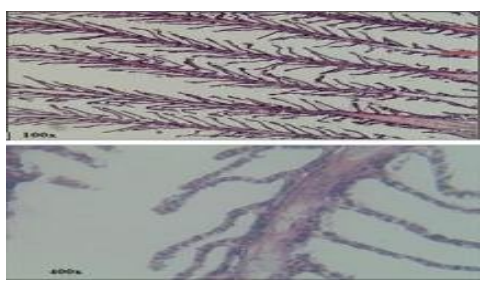

Gambar 4. Kondisi insang benih ikan kerapu bebek konsentrasi 0 $\mathrm{mg} / \mathrm{l}$ (kontrol)

Insang Benih ikan kerapu bebek pada kelompok perlakuan dengan konsentrasi 6,31 mg/l mengalami beberapa kerusakan yaitu Fusi Epitellamella Sekunder (A) yang ditandai dengan penyatuan epitellamella sekunder dapat dilihat dengan terjadinya kerusakan berupa Hyperplasi Epitellamella sekunder dan Kongesti. Terjadinya hyperplasi terlihat dengan adanya pembesaran sel epitellamella dengan bertambahnya sel dalam jumlah besar. Pada konsentrasi 3,98 $\mathrm{mg} / \mathrm{l}$ insang mengalami kerusakan yang hampir sama pada konsentrasi sebelumnya yaitu Proliferasi Epitellamella Sekunder (A) dan Kongesti (B). Namun pada konsentrasi ini, kerusakan terlihat bertambah parah dengan terjadinya Ruptur Lamella Sekunder (C), dimana kerusakan ini ditandai dengan lepasnya sel-sel dari penyokongnya sehingga insang terlihat tidak utuh. Hal ini disebabkan karena terpacunya epitel oleh adanya substansi toksik dengan kadar konsentrasi surfaktan LAS yang lebih besar (Harapan and Lubis, 2018).
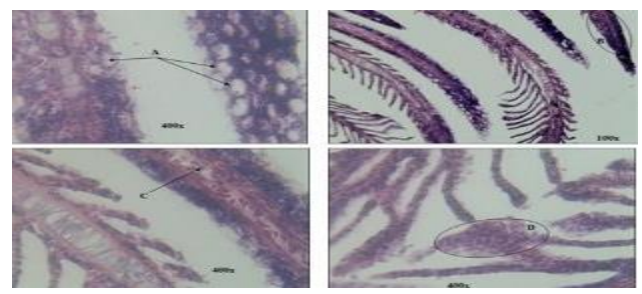

Gambar 5. Kondisi insang benih ikan kerapu bebek konsentrasi 1,58 $\mathrm{mg} / \mathrm{l}$

konsentrasi yang paling tinggi yaitu 10 $\mathrm{mg} / \mathrm{l}$. Hal ini dapat dilihat pada dimana terjadi Kongesti, Ruptur Epitellamella Sekunder dan nekrosis.

Kerusakan insang terjadi sejalan dengan semakin tingginya konsentrasi 
surfaktan LAS. Peningkatan surfaktan LAS pada insang terjadi akibat intensitas masuknya surfaktan LAS secara terus menerus ke dalam tubuh ikan. (Mubin, 2017) mengatakan bahwa yang mengandung surfaktan LAS sangat beracun bagi biota perairan. Hal ini terlihat melalui gangguan pada insang yang mengalami luka dan perubahan warna menjadi pucat. Menurut (Agustriani, Purwiyanto and Suteja, 2017), surfaktan diabsorpsi secara bersamaan dengan oksigen oleh insang kemudian dialirkan ke seluruh tubuh melalui sistem transportasi tubuh ikan.

Histologi Hati Benih Ikan Kerapu Bebek Kondisi hati pada konsentrasi 0 $\mathrm{mg} / \mathrm{l}$ atau kontrol tidak terdapat kerusakan atau masih dalam keadaan normal. Bentuk histologi hati yang normal dapat dilihat pada.

Pada konsentrasi $\quad 1,58 \quad \mathrm{mg} / \mathrm{l}$ memperlihatkan perubahan bentuk dimana pada sel hati mengalami Haemoragie (A) yang ditandai dengan eritrosit atau sel darah merah yang ditemukan di luar pembuluh darah, Kongesti (B) yang ditandai dengan tertahannya eritrosit di dalam pembuluh darah. Degenerasi Melemak (C) terjadi ditandai dengan terbentuknya vakuolalisasi dalam sel akibat pencampuran lemak dengan sitoplasma sehingga inti sel hilang dan Degenerasi Hidrofik (D) yang ditandai dengan membesarnya ukuran sel yang berisi cairan akibat perubahan tekanan osmosis sel.

Kerusakan hati benih ikan Kerapu Bebek pada konsentrasi 2,51 mg/l hampir sama dengan konsentrasi sebelumnya yaitu menyebabkan terjadinya Degenerasi Hidrofik, Kongesti, dan Haemoragie. Namun pada konsentrasi ini terdapat Melano Macrophage Center (MMC) yang ditandai dengan ditemukannya pecahan MMC. MMC berfungsi memfagosit benda-benda asing untuk pertahanan tubuh sebagai penghasil sel darah putih. menunjukkan kerusakan pada hati yaitu terjadinya Kongesti, Degenerasi Melemak, Haemoragie, Degenerasi Hidrofik, Hepatitis dan MMC.

Kerusakan lebih lanjut diperlihatkan oleh hati pada pemaparan surfaktan LAS dengan konsentrasi 6,31 mg/l yaitu terjadinya Degenerasi Hidrofik (A), Haemoragie (B), Kongesti (C), Hepatitis (D) dan Nekrosis (E). Peningkatan pada konsentrasi ini yaitu ditemukannya hepatitis yang ditandai dengan ditemukannya sel radang neutrofil serta terjadinya nekrosis atau kematian sel hepar. Struktur jaringan hati pada konsentrasi paling tinggi yaitu $10 \mathrm{mg} / \mathrm{l}$ menunjukkan kerusakan yang paling parah. Hal ini dapat dilihat pada, dimana terjadi kongesti, haemoragie, hepatitis dan nekrosis atau kematian sel hepar.

\section{KESIMPULAN}

Dari penelitian yang telah dilakukan, maka dapat diambil kesimpulan yaitu sebagai berikut :

1. Surfaktan LAS memberikan efek toksik terhadap benih Ikan Kerapu Bebek dan toksisitas meningkat seiring dengan bertambahnya konsentrasi.

2. Kadar surfaktan LAS yang mampu ditoleransi oleh benih ikan Kerapu Bebek yaitu tidak lebih dari 0,253 $\mathrm{mg} / \mathrm{l}$.

3. Konsentrasi yang berbeda surfaktan LAS memberikan pengaruh terhadap histologi insang dan hati benih Ikan Kerapu Bebek yeng menyebabkan kerusakan pada insang dan hati serta kerusakan pada insang dan hati tersebut meningkat seiring dengan bertambahnya konsentrasi.

\section{DAFTAR PUSTAKA}

Agustriani F, Purwiyanto, Sunaryo AI, Suteja Y. 2017. 'Penilaian pengkayaan logam timbal $(\mathrm{Pb})$ dan tingkat Kontaminasi air ballast di perairan tanjung api-api, sumatera 
selatan', prosiding seminar nasional hasil penelitian perikanan dan kelautan ke -VI, pp. 218-224. doi: 10.1360/zd-2013-43-6-1064.

Goang MYA, MA. 2018. 'Penyerapan senyawa merkuri (hg) di karamba jaring apung oleh tanaman azolla dengan kepadatan berbeda'. 3(1):35-42.

Harapan, Suryani F, Lubis, Tussifah L .2018. 'Kandungan logam $\mathrm{Pb}$ dan $\mathrm{Cu}$ pada daerah aliran sungai batang ayumi kota padang sidimpun sumatera utara', Prosiding seminar nasional Sinastekmapan, 116-121.

Ismarti et al. 2017. 'Heavy Metals $(\mathrm{Cu}, \mathrm{Pb}$ and $\mathrm{Cd}$ ) in Water and Angel Fish (Chelmon rostractus) from Batam Coastal, Indonesia', Omni-Akuatika. 13(1): 78-84.

Kurniawan I, Mardiadi P, Febriyeni. 2015. 'Pengaruh konsentrasi suspensi nanas dan perebusan terhadap penurunana kadar merkuri $(\mathrm{Hg})$ pada Ikan baung (mystus nemus) yang dijual di pasar'

Mei Gitarama A, Krisanti M, Ratih Agungpriyono 2016. 'Macrozoobenthic Communities and Accumulation of Chromium in
Cimanuk Lama River, West Java', Jurnal Ilmu Pertanian Indonesia (JIPI). 21(1):48-55.

Mubin M. 2017. Indentifikasi penurunan Kualitas Air Sungai dan Rawa akibat Pencemaran limbah cair pertambangan batubara.

Putri, Eka WA, Purwiyanto, anna ida suryono. 2014. ' $\mathrm{Cu}$ dan pb dalam ikan juaro (pangasius polyuronodon) dan sembilang (Paraplotosus albilaris) yang tertangkap di sungai musi bagian hilir, Sumatera Selatan', Pertanian dan ilmu kelautan-pusat kajian mitigasi bencana dan rehabilitasi pesisir, undip, p. 3.

Selatan S. et al. 2019. 'Merkuri (hg) di Permukaan Perairan Muara Sungai.

Syahrizal, Arifin MY. 2017. 'Analisis kandungan merkuri (hg) pada air dan daging ikan patin siam (Pangasius hypopthalmus) di kja Danau Jambi', Jurnal Akuakultur sungai dan Danau. 2(1):9-17.

Wiriani ER, eko, Yarifudin H, Jalius. 2018. 'Analisis Kualitas Air Sungai Batanghari Berkelanjutan Di Kota Jambi', Pembangunan berkelanjutan. 